\title{
WAWASAN SOSIO-EKONOMI PERSPEKTIF AL GHAZALI
}

\author{
Uliyatul Mu'awwanah \\ Dosen Ekonomi Syari'ah IAI Al Falah As-Sunniyyah Kencong-Jember \\ liamemoon@gmail.com
}

\begin{abstract}
As a reaction to the many manifestations of Islamic Financial Institutions in Indonesia, the ratification of Banking Law Number 10 of 1998, as well as the MUI's fatwa on bank interest, has been realized that the emergence of Islamic Financial Institutions must be accompanied by a deeper understanding of the Islamic Economic system. In this regard, the understanding of Islamic economic systems is not enough only through technical socialization, but also the background and history of the development of economic thinking of Muslim scholars to the realization of the concept of the operational mechanism of Islamic Financial Institutions. The purpose of the writing is to explain the economic thinking of Islam, one of the leaders of Muslim scientists, Abu Hamid Muhammad Al-Ghazali. Through the literary approach the author tries to present the other side of the Islamic economic atmosphere which is about socio-economic conditions.
\end{abstract}

Keywords: Socio-economics, Socialization, Islamic Financial Institutions

\begin{abstract}
ABSTRAK
Sebagai reaksi terhadap banyaknya manifestasi Lembaga Keuangan Syariah di Indonesia, pengesahan UU Perbankan Nomor 10 Tahun 1998, serta fatwa MUI tentang keharaman bunga bank, telah lahir kesadaran bahwa munculnya Lembaga Keuangan Syariah harus diiringi dengan pemahaman yang lebih dalam tentang sistem Ekonomi Islam. Berkaitan dengan hal tersebut pemahaman sistem ekonomi islam tidak cukup hanya melalui sosialisasi teknis semata, akan tetapi juga latarbelakang dan sejarah perkembangan pemikiran ekonomi para cendekiawan Muslim hingga terwujudnya konsep mekanisme operasional Lembaga Keuangan Syariah. Tujuan dari tulisan adalah menjelaskan tentang pemikiran ekonomi islam salah satu tokoh ilmuwan muslim yakni Abu Hamid Muhammad Al-Ghazali. Melalui pendekatan literatur penulis mencoba menyajikan sisi lain dari suasana ekonomi Islam yakni tentang kondisi sosio ekonomi.
\end{abstract}

Kata Kunci: Sosio-ekonomi, Sosialisasi, Lembaga Kenangan Syariah 
Uliyatul Mu'awwanah

\section{PENDAHULUAN}

Al-Ghazali adalah salah satu ilmuwan dan penulis muslim yang sangat fenomenal, lahir di Persia. Perhatian Al-Ghazali tidak terfokus pada satu bidang tertentu namun juga meliputi seluruh aspek kehidupan manusia, hal ini terlihat dari begitu banyak karya kitab yang telah ditulisnya dalam banyak bidang seperti Teologi yaitu Al-Wasith, Al-Basith al-Wajiz, Spiritual dan moral yaitu IhyaUlumuddin dan Kimiya-i-Sa"adat, dalam bidang Fiqh terdapat karya Al-Ghazali yaitu Al-Wajiz, Al-Iqtishad fil I'tiqad dan masih karya lain yang menurut sejarah adalah lebih dari 300 judul karya.

Secara jelas, karya Al-Ghazali memang tidak spesifik yang membahas tentang ekonomi islam namun perhatian dan pembahasannya itu terkandung dalam berbagai analisis kajian fiqihnya karena ekonomi islam pada hakikatnya ekonomi islam adalah bagian yang tidak terpisahkan dari ilmu fiqh islam.

Dalam Islam, perilaku sosial merupakan salah satu unsur dalam kehidupan bermasyarakat. Manusia dalam segi bathiniyah diciptakan dengan berbagai macam naluri, di antaranya memiliki naluri sebagai makhluk sosial yakni saling membutuhkan satu sama lain, hal itulah yang disebut fitrah. Qodrati semacam ini yang membuat manusia memiliki kebutuhan dan selalu tergerak untuk mencukupi kebutuhan hidupnya.

Manusia dipandang sebagai maximizers yakni sebuah ungkapan yang menjelaskan bahwa manusia memiliki keinginan selalu ingin lebih. Al-Ghazali tidak hanya menyadari keinginan manusia untuk mengumpulkan kekayaan tetapi juga kebutuhannya untuk persiapan dimasa depan. Namun demikian ia memperingatkan bahwa jika semangat selalu ingin lebih ini menjurus kepada keserakahan dan pengejaran nafsu pribadi, hal itu wajib dihindari karena sesuatu hal yang buruk dan pantas dikutuk. Dalam hal ini, ia memandang kekayaan sebagai ujian terbesar

\section{Biografi Al-Ghazali}

Imam Al-Ghazali bernama lengkap Muhammad bin Muhammad bin $\mathrm{Mu}$ hammad Al-Ghazali Al-Thusi. Lahir di kota Thus, Iran pada 445 H/1058 M. Bakat intelektualnya terlihat sejak anak-anak, terutama setelah mendapat didikan dari ulama berwawasan ablu sunah wal-jamaah. Dia sempat direkrut menjadi pimpinan ulama yang memberikan pengesahan pada keputusan-keputusan pemerintah. Namun tampaknya dia lebih betah menjadi tenaga pengajar di Universitas $\mathrm{Al}$ Nizhamiyah, Baghdad. Dari karyanya yang banyak, pemikirannya yang luas, dan sikapnya yang arif, banyak masyarakat yang mengaguminya dan memberikan gelar Hujjat Al-Islam. Setelah merampungkan hampir 100 buku dari berbagai tema, dia dipanggil oleh Allah pada hari Senin, 14 Jumadil Akhir 505 H.

108 | FaLASIFA, Vol. 10 Nomor 1 Maret 2019 
Sejak kecil, Hujjatul Islam Abu Hamid Muhammad Al-Tusi Al-Ghazali hidup di dunia tasawuf. Ia tumbuh dan berkembang dalam asuhan seorang sufi setelah ayahnya yang juga seorang sufi meninggal dunia. ${ }^{1}$ Sejak muda Al-Ghazali sangat antusias terhadap ilmu pengetahuan. Ia pertama-pertama belajar bahasa Arab dan Fiqih di kota Tus, kemudian pergi ke kota Jurjan untuk belajar dasardasar Ushul Fiqh. Setelah kembali ke kota Tus selama beberapa waktu, ia pergi ke Naisabur untuk melanjutkan rihlah ilmiahnya. Di kota ini, Al-Ghazali belajar kepada Al-Haramain Abu Al-Ma'ali Al-Juwaini sampai akhir hayatnya.

Selain mengajar, Al-Ghazali juga melakukan bantahan-bantahan terhadap berbagai pemikiran Bathniyah, Ismailiyah, filosof, dan lain-lain. Pada masa ini, sekalipun telah menjadi guru besar, ia masih merasakan kehampaan dan keresahan dalam dirinya. Akhirnya, setelah merasakan bahwa hanya kehidupan sufistik yang mampu memenuhi kebutuhan rohaninya, Al-Ghazali memutuskan untuk menempuh tasawuf sebagai jalan hidupnya.

Oleh karena itu, pada tahun $488 \mathrm{H}$ (1095 M), Al-Ghazali meninggalkan Baghdad dan pergi menuju Syria untuk merenung, membaca, dan menulis selama kurang lebih 2 tahun. Kemudian, ia pindah ke Palestina untuk melakukan aktivitas yang sama dengan mengambil tempat di Baitul Maqdis. Setelah menunaikan ibadah haji dan menetap beberapa waktu di kota Iskandariah, Mesir, Al-Ghazali kembali ke tempat kelahirannya, Tus, pada tahun 499 H (1105 M) untuk melanjutkan aktivitasnya, berkhalwat dan beribadah. Proses pengasingannya tersebut berlangsung selama 12 tahun dan, dalam masa ini, ia banyak menghasilkan berbagai karyanya yang terkenal, seperti Kitab Ihya Ulum al-Din.

\section{PEMBAHASAN}

\section{Konsep Kesejahteraan Sosial Islami}

Perilaku individu menjadi salah satu perhatian Al-Ghazali untuk dibahas dalam berbagai kajiannya yang tertuang dalam studi fiqih melalui perspektif $\mathrm{Al}$ Quran, Sunnah, Fatwa-fatwa sahabat dan Tabi'in serta petuah-petuah para sufi terkemuka pada masa sebelumnya seperti Junaid Al-Baghdadi, Dzun Nun AlMishri, dan Harits bin Asad Al-Muhasibi. Namun demikian Al-Ghazali senantiasa menggunakan pendekatan Tasawuf karena pada masanya, orang-orang kaya dan berkuasa sulit menerima pendekatan selain Tasawuf dalam mempercayai hari kiamat.

${ }^{1}$ S. M. Ghazanfar dan Abdul Azim Islahi, Economic Thought of An Arab Scholastic: Abu Hamid Al-Ghazali, dalam History of Political Economy (Durham: Duke University Press, 1990), Vol. 2, No. 22, hlm. 381-402

FaLASIFA, Vol. 10 Nomor 1 Maret 2019 | 109 
Sesuatu yang menjadi pangkal tolak seluruh karya Al-Ghazali adalah kebaikan bersama atau maslahat (utilitas). Kesejahteraan sosial islami adalah sebuah konsep yang mencakup seluruh aktivitas manusia serta berkaitan erat antara individu dengan masyarakat, bahkan dalam meningkatkan kesejahteraan sosial AlGhazali telah mengidentifikasi semua masalah baik yang berupa utilitas (kegunaan/manfaat/masalib) maupun disutilitas/ kerusakan. Selanjutnya ia juga mendefiniskan fungsi sosial dalam kerangka hierarki kebutuhan individu dan sosial. ${ }^{2}$

Dalam kitab Ihya'Ulum al-Din Al Ghazali Menjelaskan bahwa maslahah atau kesejahteraan dari suatu masyarakat tergantung kepada pencarian dan pemeliharaan lima tujuan dasar, yakni al-dien/(agama), nafs (hidup atau jiwa), nasl (keluarga atau keturunan), mal (harta atau kekayaan), dan $a q l$ (intelektual/akal). Ia menitikberatkan bahwa sesuai tuntunan wahyu, tujuan utama kehidupan umat manusia adalah untuk mencapai maslabat al-din wa al-dunya (kebaikan dunia dan akhirat). ${ }^{3}$

\section{Tripartite Kesejahteraan dalam Hierarki Utilitas Individu dan Sosial}

Terdapat sebuah klasifikasi yang disebut kebutuhan ordinal peninggalan tradisi Aristotelian yakni kebutuhan dasar, kebutuhan terhadap barang-barang eksternal dan kebutuhan terhadap barang-barang psikis. ${ }^{4}$ Selanjutnya Al-Ghazali menjelaskan hierarkinya tentang utilitas individu dan sosial yang meliputi kebutuhan (daruriyat), kesenangan atau kenyamanan (bajat), dan kemewahan (tahsinaat). Lebih jelasnya jika dikaitkan dengan para ekonom kontempoter disebut kebutuhan primer, sekunder dan tersier.

Kesejahteraan sosial islami yang dimaksudkan Al-Ghazali di atas dapat tercapai jika ke lima tujuan dasar terpelihara dengan baik, sedangkan dalam pemeliharaannya hierarki utilitas bagian pertama hingga ketiga adalah sebagai kuncinya, ketiga kebutuhan individu dan sosial ini harus sedapat mungkin terpenuhi dengan baik meskipun cenderung fleksibel, mengikuti waktu, tempat, dan sesuai dengan kemampuan. Kebutuhan pertama yakni kebutuhan daruriyat seperti halnya makanan, pakaian, dan tempat tinggal yang layak. Kebutuhan kedua yakni hajat, meliputi seluruh hal dan kegiatan yang tidak pokok namun dibutuhkan untuk menunjang kebutuhan pertama serta menghilangkan kesulitan dalam hidup atau kesenangan dan kenyamanan, terakhir kebutuhan ketiga yakni semua hal yang bukan

${ }^{2}$ Adimarwan Azwar Karim, Sejarah Pemikiran Ekonomi Islam (Jakarta: Rajawali Pers, 2016), hlm. 318

${ }^{3}$ Abu Hamid Al- Ghazali, Ihya Ulum al-Din (Beirut: Dar al-Nadwah, t.t.), Juz 2, hlm. 109

${ }^{4}$ S. Tood Lowry, The Archeology of Economic Ideas: The Classical Greek Tradition (Durham: Duke University Press, 1987), hlm. 220

110 | FalAsIfA, Vol. 10 Nomor 1 Maret 2019 
sekedar hajat namun lebih jauh lagi guna untuk melengkapi serta menghiasi hidup seorang individu (barang mewah).

\section{Sketsa Umum Sosio Ekonomi Al-Ghazali}

Al-Ghazali memandang perkembangan ekonomi adalah sebuah tugas sosial, yakni kewajiban yang sudah ditetapkan Allah, jika kewajiban ini tidak dilaksanakan maka kehidupan ini akan runtuh dan kemanusiaan akan binasa. Ia menegaskan bahwa aktivitas ekonomi harus dilakukan secara efisien karena merupakan bagian dari pemenuhan tugas keagamaan seseorang. ${ }^{5}$ Kemudian ia menjelaskan berbagai argumen mengapa individu harus melakukan aktivitas ekonomi di antaranya adalah untuk memenuhi kebutuhan hidup, untuk mensejahterakan keluarga serta untuk membantu orang lain yang membutuhkan.

Namun demikian, Al-Ghazali juga mengkritik mereka yang usaha hanya sekedar untuk memenuhi kebutuhan atau penyambung hidup saja. Menurut AlGhazali jika orang-orang tetap tinggal pada tingkatan subsisten (saad al ramaq) dan menjadi sangat lemah, angka kematian akan meningkat, semua pekerjaan dan kerajinan akan berhenti, dan masyarakat akan binasa. Selanjutnya agama akan hancur karena kehidupan dunia adalah persiapan bagi kehidupan akhirat. ${ }^{6}$

\section{Mekanisme, Etika Pasar dan Ekspor-Impor}

Bagi Al-Ghazali, pasar merupakan bagian dari keteraturan alami. Pasar berevolusi sesuai dengan hukum alam yaitu sebuah representasi alami yang timbul dari individu untuk saling memenuhi berbagai kebutuhan ekonomi. Kedalaman dan keluasan corak pemikirannya ia jelaskan secara rinci seperti kutipan di bawah ini:

"Mungkin saja petani hidup ketika peralatan pertanian tidak tersedia. Sebaliknya, pandai besi dan tukang kayu hidup di tempat yang tidak memiliki lahan pertanian. Jadi, petani membutuhkan pandai besi dan tukang kayu, dan mereka pada gilirannya membutuhkan petani. Secara alami, masingmasing akan ingin untuk memenuhi kebutuhannya dengan memberikan sebagian miliknya untuk dipertukarkan. Dapat pula terjadi tukang kayu membutuhkan makanan dengan menawarkan alat-alatnya, tetapi petani tidak membutuhkan alat-alat tersebut. Atau, jika petani membutuhkan alat-alat, tukang kayu tidak membutuhkan makanan. Keadaan ini menimbulkan masalah. Oleh karena itu, secara alami pula orang akan terdorong untuk menyediakan tempat penyimpanan alat-alat di satu pihak dan tempat penyim-

\footnotetext{
${ }^{5}$ Abu Hamid Al-ghazali, Mizan al-Amal (Kairo: Dar al-Ma’arif, 1964), hlm.377

${ }^{6}$ Abu Hamid Al-Ghazali, Op. Cit., hlm. 108
}

FaLASIFA, Vol. 10 Nomor 1 Maret 2019 | 111 
panan hasil pertanian di lain pihak. Tempat inilah yang kemudian didatangi pembeli sesuai dengan kebutuhannya masing-masing sehingga terbentuklah pasar. Petani, tukang kayu dan pandai besi yang tidak dapat langsung melakukan barter, juga terdorong pergi ke pasar ini. Bila di pasar juga tidak ditemukan orang yang mau melakukan barter, ia akan menjual pada pedagang dengan harga yang relative murah untuk kemudian disimpan sebagai persediaan. Pedagang kemudian menjualnya dengan suatu tingkat keuntungan (laba). Hal ini berlaku untuk setiap jenis barang."” (Ihya Ulumudin, III: 227).

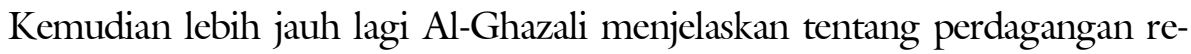
gional atau yang kita kenal sebagai teori Ekspor-Impor. Simak kutipannya sebagai berikut:

"Selanjutnya praktik-praktik ini terjadi di berbagai kota dan Negara. Orangorang melakukan perjalanan ke berbagai tempat untuk mendapatkan alatalat dan makanan dan membawanya ke tempat lain. Urusan ekonomi orang akhirnya diorganisasikan ke kota-kota yang mungkin tidak memiliki semua alat-alat yang dibutuhkan, dan ke desa-desa yang mungkin tidak memiliki semua bahan makanan yang dibutuhkan. Keadaan inilah yang pada gilirannya menimbulkan kebutuhan alat transportasi. Terciptalah kelas pedagang regional dalam masyarakat. Motifnya tentu saja mencari keuntungan. Para pedagang ini bekerja keras memenuhi kebutuhan orang lain dan mendapat keuntungan dan keuntungan ini akhirnya dimakan oleh orang lain juga"s

Menurut Al-Ghazali mekanisme pasar adalah harga yang berlaku, ditentukan oleh praktek-praktek pasar, yang terbentuk karena teori permintaan dan penawaran. Teori permintaan al-Ghazali yang turun dari kiri atas ke kanan bawah, dijelaskannya "harga dapat diturunkan dengan mengurangi permintaan". Sedangkan teori penawaran al-Ghazali, yaitu naik dari kiri bawah ke kanan atas, yang dinyatakannya "jika petani tidak mendapatkan pembeli barangnya, ia akan menjual pada harga yang lebih murah”. Bagi al-Ghazali, keuntungan (ribh) atau laba, merupakan kompensasi dari kesulitan perjalanan, resiko bisnis dan ancaman keselamatan si pedagang. Meskipun al-Ghazali menyebut keuntungan dalam tulisannya, tetapi kita bisa paham, bahwa yang dimaksudkannya adalah harga. Artinya, harga bisa dipengaruhi oleh keamanan perjalanan, resiko, sebagainya. Perjalanan yang aman akan mendorong masuknya barang impor dan menimbulkan peningkatan penawaran, akibatnya harga menjadi turun. Keseimbangan pasar bagi al-Ghazali,

\footnotetext{
${ }^{7}$ Ibid., Juz 3, hlm 227

${ }^{8}$ Loc. Cit.
}

112 | FaLASIFA, Vol. 10 Nomor 1 Maret 2019 
terjadi ketika penawaran dan permintaan terhadap produk petani dalam keadaan rela sama rela (ridho). Berkaitan dengan hal ini, Al Ghazali menyatakan bahwa laba normal adalah berkisar antara 5-10 persen dari harga barang ${ }^{9}$, lebih jauh lagi ia menekankan bahwa seorang penjual hendaknya didorong oleh keuntungan atau laba yang hakiki yakni akhirat.

Sedangkan Etika (akhlak) adalah keadaan batin yang menjadi sumber lahirnya suatu perbuatan dimana perbuatan itu lahir secara spontan, mudah, tanpa menghitung untung rugi. Orang yang berakhlak baik, ketika menjumpai orang lain yang perlu ditolong maka ia secara spontan menolongnya tanpa sempat memikirkan risiko. Demikian juga orang yang berakhlak buruk secara spontan melakukan kejahatan begitu peluang terbuka. Menurut Al-Ghazali, pasar harus berfungsi berdasarkan etika dan moral para pelaku pasar karena aktivitas pasar adalah aktivitas yang mengarah pada peningkatan nilai tambah melalui proses penyerahan jasa, perdagangan atau pengolahan barang (produksi).

Moral adalah faktor yang mendorong seseorang melakukan perbuatan yang baik, etika adalah sebuah rambu-rambu didalam bertindak yang akan membimbing dan mengingatkan kita untuk melakukan perbuatan yang terpuji yang harus selalu dipatuhi dan dilaksanakan. Secara rinci Al-Ghazali mengecam tentang pengambilan keuntungan dengan cara menimbun makanan dan bahan-bahan kebutuhan dasar lainnya. Selain itu, menimbun uang dari peredaran juga termasuk kezaliman besar karena dengan menimbun jelas akan memperlambat perputaran uang, ini berarti akan memperkecil terjadinya transaksi perekonomian terutama ekonomi yang lemah dan bisnispun akan macet. Lebih jauh lagi tentang manipulasi harga serta iklan palsu, pemberian informasi asimetris mengakibatkan kesenjangan antara barang yang dijual dengan keadaan sesungguhnya seperti jumlah, berat, kualitas, serta kondisi fisiknya, hal ini juga termasuk kejahatan pasar yang harus dihilangkan. Al Ghazali sangat menekankan nilai kebenaran dan kejujuran dalam bisnis. Berdasarkan dari hal tersebut bisa dipertajam bahwa konsep etika pasar menurut Al-Ghazali adalah berilmu sebelum beramal selanjutnya memaksimalkan keuntungan bukanlah sebuah kebajikan, bersikap adil dan peduli kepada stakeholder serta senantiasa berupaya mewujudkan kebaikan untuk banyak pihak.

\section{Kegiatan Produksi}

Al-Ghazali memberikan perhatian yang cukup besar ketika menggambarkan berbagai macam aktivitas produksi dalam sebuah masyarakat, termasuk hierarki

9 Abu Hamid Al-Ghazali, Kimiya-e-Sa’adat (Lahore: Naashraan-e-Quran Ltd, 1973), hlm.358

FalASIFA, Vol. 10 Nomor 1 Maret 2019 | 113 
dan karakteristiknya. Ia mengklasifikasi aktivitas produksi menurut kepentingan sosialnya serta menitikberatkan perlunya kerja sama dan kordinasi. Fokus utamanya adalah tentang jenis aktivitas yang sesuai dengan dasar-dasar etos Islam. ${ }^{10}$

Seperti yang telah dikemukakan, Al-Ghazali menganggap kerja sebagai bagian dari ibadah seseorang. ${ }^{11}$ Bahkan secara khusus, ia memandang bahwa produksi barang-barang kebutuhan dasar sebagai kewajiban sosial (fard al kifayah). ${ }^{12}$ Hal ini berarti, jika ada sekelompok orang yang berkecimpung di dunia usaha yang memproduksi barang-barang tersebut dalam jumlah yang mencukupi kebutuhan masyarakat, maka kewajiban seluruh masyarakat telah terpenuhi. Namun, jika tidak seorangpun yang melibatkan diri dalam kegiatan tersebut atau jika jumlah yang diproduksi tidak mencukupi kebutuhan masyarakat, semua orang akn dimintai pertanggungjawabannya di akhirat. Dalam hal ini, pada prinsipnya, Negara harus bertanggung jawab dalam menjamin kebutuhan masyarakat terhadap barang-barang kebutuhan pokok. Di samping itu, Al-Ghazali beralasan bahwa ketidakseimbangan antara jumlah barang kebutuhan pokok yang tersedia dengan yang dibutuhkan masyarakat cenderung akan merusak kehidupan masyarakat.

Hierarki produksi yang diberikan Al-Ghazali secara garis besar meliputi industri dasar yakni industry-industri yang menjaga kelangsungan hidup manusia. Kelompok ini terdiri dari empat jenis aktivitas, yaitu agrikultur untuk makanan, tekstil untuk pakaian, konstruksi untuk perumahan, dan aktivitas Negara, termasuk penyediaan infrastuktur, khususnya untuk memfasilitasi produksi kebutuhan barang-barang pokok dan untuk meningkatkan kerja sama dan kordinasi antar pihak-pihak yang terlibat dalam produksi. Selanjutnya yakni Aktivitas Penyokong, adalah aktivitas yang bersifat tambahan bagi industri dasar, seperti industri baja, eksplorasi dan pengembangan tambang serta sumber daya hutan. Terakhir yakni Aktivitas Komplementer, adalah yang berkaitan dengan industry dasar, seperti penggilingan dan pembakaran produk-produk agrikultur. Ketiganya hampir mirip dengan pembahasan dalam kontemporer yaitu primer (agrikultur), sekunder (manufaktur), dan tersier (jasa).

Al-Ghazali mengakui bahwa kelompok pertama adalah kelompok yang paling penting dan peranan pemerintah sebagai kekuatan mediasi dalam kelompok ini cukup krusial. Dengan klasifikasi ini, ia percaya bahwa untuk menjamin keserasian lingkungan sosio ekonomi, ketiga kelompok aktivitas tersebut harus diting-

${ }^{10}$ Adimarwan Azwar Karim, Sejarah Pemikiran Ekonomi Islam (Jakarta: Rajawali Pers, 2016), hlm. 328

${ }^{11}$ Abu Hamid Al- Ghazali, Ihya Ulum al-Din (Beirut: Dar al-Nadwah, t.t.), Juz 2, hlm 61

${ }^{12}$ Ibid, blm. 83

114 | FaLASIFA, Vol. 10 Nomor 1 Maret 2019 
katkan secara aktif. Pemenuhan ketiganya merupakan kewajiban sosial atau suatu tugas ilahiah.

Al-Ghazali juga mengakui adanya tahapan produksi yang beragam sebelum produk tersebut dikonsumsi. Selanjutnya, ia meyadari kaitan yang sering kali terdapat dalam mata rantai produksi. Berkaitan dengan hal ini, ia menyatakan,

"Petani memproduksi gandum, tukang giling mengubahnya menjadi tepung, lalu tukang roti membuat roti dari tepung itu ”

Tentang saling ketergantungan dalam produksi, ia mengemukakan:

"Selanjutnya pandai besi membuat peralatan cangkul bagi petani, dan tukang kayu memproduksi peralatan yang dibutuhkan oleh pandai besi. Hal yang sama berlaku bagi mereka yang terlibat dalam produksi peralatan dan perkakas yang dibutuhkan untuk memproduksi bahan makanan"13

Tahapan dan keterkaitan produksi yang beragam mensyaratkan adanya pembagian kerja, koordinasi dan kerja sama. Al-Ghazali memberikan gambarang yang jelas mengenai hal ini:

"Hendaklah anda ketahui bahwa tumbuhan dan hewan tidak dapat langsung dimakan dan dicerna. Semuanya membutuhkan transformasi, pembersihan, pencamuran, dan pemasakan sebelum dapat dikonsumsi. Roti misalnya, dinilai dengan petani yang menyiapkan dan mengolah bajak tanah. Kemudian tanah tersebut diairi, dibersihkan dari rumput liar lalu hasilnya dipanen, dan bulir-bulir gandumnya dibersihkan dan dipisahkan. Kemudian gandum itu digiling menjadi tepung sebelum dipanggang. Bayangkan sajaberapa banyak pekerjaan terlibat; dan kita hanya menyebutkan beberapa saja di sini. Dan bayangkan jumlah orang yang mengerjakan pekerjaan-pekerjaan yang beragam ini, jumlah macam-macam perkakas, yang terbuat dari besi, kayu, batu, dan lain-lain. Bila diselidiki, kita akan menemukan bahwa mungkin satu kerat roti dapat menjadi roti yang siap dimakan dengan bantuan mungkin lebih dari seribu pekerja $" 14$

\title{
Problematika Sistem Barter, Evolusi Uang dan Larangan Riba
}

Al-Ghazali mempunyai wawasan yang sangat luas dan mendalam tentang berbagai kesulitan yang timbul dari pertukarangan barter di satu sisi dan di sisi lain, signifikansi uang dalam kehidupan umat manusia ${ }^{15}$. Secara detail ia menja-

\author{
${ }^{13}$ Ibid., Juz 4, hlm, 128 \\ ${ }^{14}$ Ibid.,hlm. 118. \\ 15 Adimarwan Azwar Karim, Sejarah Pemikiran Ekonomi Islam (Jakarta: Rajawali
} Pers, 2016), hlm. 334

FaLASIFA, Vol. 10 Nomor 1 Maret 2019 | 115 
Uliyatul Mu'awwanah

barkan hal sebagai berikut:

"Pencipataan dirham dan dinar (koin emas dan perak) adalah salah satu karunia Allah. Semua transaksi ekonomi didasarkan dua jenis uang ini. Dinar dan dirham adalah logam yang tidak memberikan manfaat secara langsung. Namun orang membutuhkannya untuk mempertukarkannya dengan bermacam-macam barang lainnya, seperti makanan, pakaian dan lain-lain. Kadangkala seseorang membutuhkan barang yang dimilikinya dan ia memiliki barang yang tidak dibutuhkannya. Contohnya, seseorang memiliki kunyit, tetapi ia membutuhkan unta untuk transportasi. Orang yang lain memiliki unta tetapi tidak membutuhkannya sekarang, tetapi ia menginginkan kunyit. Bagaimanapun juga, harus ada ukuran untuk mempertukarkan kedua objek tersebut, karena pemilik unta tidak dapat menyerahkan untanya dalam bentuk utuh untuk dipertukarkan dengan sejumlah kecil kunyit. Tidak ada kesamaan antara keduanya yang memungkinkan kita menentukan jumlah yang sama menyangkut berat dan bentuknya. Barang-barang ini tidak memiliki kesetaraan untuk diperbandingkan secara langsung sehingga kita tidak dapat mengetahui berapa banyak kunyit yang harus disediakan supaya setara dengan nilai unta. Transaksi barter ini sangat sulit. Barang-barang seperti ini memerlukan media yang dapat menentukan nilai tukarnya secara adil. Bila tempat dan kelasnya dapat diketahui dengan pasti, menjadi mungkin untuk menentukan nama barang yang memiliki nilai yang sama dan mana yang tidak. Jadi ditentukanlah bahwa misalnya seekor unta sama dengan 100 dinar dan kunyit sejumlah tertentu sama dengan 100 dinar. Karena masingmasing barang tersebut sama dengan sejumlah dinar tertentu, kedua jumlah tersebut sama satu sama lain. Namun, dinar dan dirham itu tidak dibutuhkan semata-mata karena logamnya. Dinar dan dirham diciptakan untuk dipertukarkan dan untuk membuat aturan pertukaran yang adildan untuk membeli barang-barang yang memiliki kegunaan. Sesuatu (seperti uang) dapat dengan pasti dikaitkan dengan sesuatu yang lain jika sesuatu itu memiliki bentuk atau fitur khususnya sendiri- contohnya cermin tidak memiliki warna tetapi dapat memantulkan semua warna."

Penjelasan tersebut menunjukkan bahwa Al-Ghazali mempunyai wawasan yang sangat komprehensif mengenai berbagai problema barter yang dalam istilah modern disebut sebagai lack of common denominator (kurang memiliki angka penyebut yang sama), indivisibility of goods (barang tidak dapat dibagi-bagi), dan

${ }^{16}$ Abu Hamid Al- Ghazali, Ihya Ulum al-Din (Beirut: Dar al-Nadwah, t.t.), Juz 2, hlm 91-93

116 | FaLASIFA, Vol. 10 Nomor 1 Maret 2019 
double coincidence of wants (keharusan adanya dua keinginan yang sama). ${ }^{17}$ Walaupun dapat dilakukan, pertukaran barter menjadi sagat tidak efisien karena adanya perbedaan karakteristik barang-barang (seperti unta dan kunyit). Pemilihan berbagai contoh tersebut mencerminkan pemahaman Al-Ghazali yang sangat baik terhadap problem barter. Ia menegaskan bahkan evolusi uang terjadi hanya karena kesepekatan dan kebiasaan (konvensi), yakni tidak aka nada masyarakat tanpa pertukaran barang dan tidak tidak ada pertukaran yang efektif tanpa ekuivalensi, dan ekuivalensi demikian hanya dapat ditentukan dengan tepat apabila ada ukuran yang sama.

Al-Ghazali juga terlihat tidak hanya menyadari dasar fundamental dari nilai suatu barang, yakni utilitas dan kegunaannya, tetapi juga nilainya dalam pertukaran. Kedua konsep ini-nilai guna dan nilai tukar-menjadi sangat signifikan dalam perdebatan selanjutnya yang dilakukan oleh para ekonom pada beberapa abad kemudian.

Seperti yang telah disinggung, Al-Ghazali terlihat begitu memahami berbagai macam fungsi uang. Dalam hal ini, ia menekankan bahwa uang tidak diinginkan karena uamg itu sendiri. Uang baru akan memiliki nilai jika digunakan dalam suatu pertukaran. Lebih jauh, Al-Ghazali menyatakan bahwa tujuan satu-satunya dari emas dan perak adalah untuk dipergunakan sebagai uang (dinar dan dirham). Ia mengutuk mereka yang menimbun kepingan-kepingan uang atau mengubahnya menjadi bentuk yang lain:

"Jika seseorang menimbun dirham dan dinar, ia berdosa. Dinar dan dirham tidak memiliki guna langsung pada dirinya. Dinar dan dirham diciptakan supaya beredar dari tangan ke tangan, untuk mengatur dan memfafisilitasi pertukaran...(sebagai) symbol untuk mengetahui nilai dan kelas barang. Siapapun yang mengubahnya menjadi peralatan-peralatan emas dan perak berarti ia tidak bersyukur kepada penciptanya dan lebih buruk dari pada penimbun uang, karena orang seperti itu adalah seperti orang yang memaksa penguasa untuk melakukan fungsi-fungsi yang tidak cocok-seperti menenun kain, mengumpulkan pajak, dan lain-lain. Menimbun koin masih lebih baik dibandingkan mengubahnya, karena ada logam dan material lainnya seperti tembaga, perunggu, besi, tanah liat yang dapat digunakan untuk mengganti fungsi yang dijalankan oleh dirham dan dinar." 18

17 Adimarwan Azwar Karim, Sejarah Pemikiran Ekonomi Islam (Jakarta: Rajawali Pers, 2016), hlm. 335

${ }^{18}$ Abu Hamid Al- Ghazali, Ihya Ulum al-Din (Beirut: Dar al-Nadwah, t.t.), Juz 2, hlm 91-93

FaLASIFA, Vol. 10 Nomor 1 Maret 2019 | 117 
Menurut sejarah, emas dan perak merupakan logam terpenting yang digunakan sebagai uang komoditas. Pemerintah mulai mencetak koin-koin ini untuk menghindari penimbangan yang memakan biaya yang tinggi setiap kali terjadi transaksi. Uang dapat diproduksi secara pribadi hanya dengan membawa emas dan perak yang sudah ditambang ke percetakan. Dengan standar uang komoditas, dulunya muatan logam suatu koin sama nilainya dengan koin tersebut sebagai uang. Atas dasar ini, jika ditemukan lebih banyak emas dan perak, persediaan uang akan naik, demikian juga harga akan naik, dan nilai uang akan turun. Demikian penjelasan sederhana mengenai siklus inflasioner-deflasioner di bawah standar uang komoditas. ${ }^{19}$

Walaupun analisisnya tidak begitu spesifij, tampaknya Al-Ghazali sudah menguasai dasar-dasar teori siklus ni. Perhatiannya terutama ditujukan pada problem yang muncul akibat pemalsuan dan penurunan nilai-mencampur logam kelas rendah dengan koine mas atau perak, atau memotong/mengikis muatan logamnya. Ia menganggap pemalsuan uang sebagai bukan hanya dosa perorangan, tetapi terutama berpotensi merugikan masyarakat secara umum:

"Memasukkan uang palsu dalam peredaran merupakan suatu kedhaliman yang besar. Semua yang memegangnya dirugikan...peredaran satu dirham palsu lebih buruk dari pada mencuri seribu dirham, karena tindakan mencuri merupakan sebuah dosa, yang langsung berakhir setelah dosa itu diperbuat; tetapi pemalsuan uang merupakan sesuatu yang berdampak pada banyak orang yang menggunakannya dalam transaksi selama jangka waktu yang lama. ${ }^{20}$

Mengenai penurunan nilai uang, Al-Ghazali menyatakan:

"Zaif [suasa, logam campuran], maksudnya adalah unit uang yang sama sekali tidak mengandung perak; hanya polesan atau dinar yang tidak mengandung emas. Jika sekeping koin mengandung sejumlah perak tertentu, tetapi dicampur dengan tembaga, dan itu merupaka koin emas resmi dalam negara tersebut, maka hal ini dapat diterima, baik muatan peraknya diketahui ataupun tidak. Namun, jika koin itu tidak resmi, koin itu dapat diterima hanya jika muatan peraknya diketahui."21

${ }^{19}$ Adimarwan Azwar Karim, Sejarah Pemikiran Ekonomi Islam (Jakarta: Rajawali Pers, 2016), hlm. 337

${ }^{20}$ Abu Hamid Al- Ghazali, Ihya Ulum al-Din (Beirut: Dar al-Nadwah, t.t.), Juz 2, hlm 73

${ }^{21}$ Ibid.,hlm 74

118 | FaLASIFA, Vol. 10 Nomor 1 Maret 2019 
Bagi Al-Ghazali, larangan riba yang sering kali dipandang sama dengan bunga adalah mutlak. Terlepas dari alas an "dosa", argument lainnya yang menentang riba adalah kemungkinan terjadinya eksploitasi ekonomi dan ketidakadilan dalam transaksi. Namun, Al-Ghazali membahas transaksi selain pinjam-meminjam bunga mungkin timbul dalam bentuk yang terselubung.

Al-Ghazali seperti halya para ilmuwan muslim dan eropa, pada umumnya mengasumsikan bahwa nilai suatu barang tidak terkait dengan berjalannya waktu. Dengan asumsi ini, ia beralasan bahwa terdapat du acara di mana bunga dapat muncul dalam bentuk yang tersembunyi, yakni: pertama, bunga dapat muncul jika ada pertukaran emas dengan emas, tepung dengan tepung, dan sebagainya, dengan jumlah yang berbeda atau dengan waktu penyerahan yang berbeda. Jika waktu penyerahannya tidak segera, dan ada permintaan untuk melebihkan jumlah komoditi, kelebihan ini disebut riba al-nasiah (bunga yang timbul karena keterlambatan membayar atau keterlambatan penyerahan barang). Jika jumlah komoditas yang dipertukarkan tidak sama tetapi pertukaran terjadi secara simultan, kelebihan yang diberikan dalam pertukaran tersebut disebut riba al-fadl (bunga yang timbul karena kelebihan pembayaran). Menurut Al-Ghazali, kedua bentuk transaksi tersebut haram hukumnya. Jadi agar kedua jenis riba ini tidak timbul, pertukaran harus dilakukan dengan kuantitas yang sama dan transfer kepemilikan harus simultan. Kalau tidak bunga yang tersembunyi mungkin timbul. Namun, jika pertukaran melibatkan komoditas dengan jenis yang sama, seperti logam (emas dan perak) atau bahan makanan (gandum dan gerst), hanya riba al-nasiah yang dilarang, sementara riba al-fadl dibolebkan. bila pertukarannya antara komoditas dengan jenis yang berbeda (logam dan makanan), keduanya diperbolehkan.

Selanjutnya Al-Ghazali menyatakan bahwa menetapkan bunga atas piutang berarti membelokkan uang dari fungsi utamanya, yakni untuk mengukur kegunaan objek pertukaran. Oleh karena itu, bila jumlah uang yang diterima lebih banyak dari pada jumlah uang yang diberikan, akan terjadi perubahan standar nilai. Perubahan ini terlarang. Seperti kutipan di bawah ini:

“jika seseorang memperdagangkan dinar dan dirham untuk mendapatkan dinar dan dirham lagi, ia menjadikan dinar dan dirham sebagai tujuannya. Hal ini berlawanan dengan fungsi dinar dan dirham. Uang tidak diciptakan untuk menghasilkan uang. Melakukan hal ini merupakan pelanggaran. Dinar dan dirham adalah alat untuk mendapatkan barang-barang lainnya. Mereka tidak dimaksudkan bagi mereka sendiri. Dalam hubungannya dengan barang lainnya, dinar dan dirham adalah seperti preposisi dalam kalimatdigunakan untuk memberikan arti yang tepa tatas kata-kata. Atau seperti cermin yang memantulkan warna, tetapi tidak memiliki warna sendiri. Bila orang diperbolehkan untuk menjual (atau mempertukarkan) uang dengan

FaLASIFA, Vol. 10 Nomor 1 Maret 2019 | 119 
uang (untuk mendapatkan laba ), transaksi seperti ini akan menjadi tujuannya, sehingga uang akan tertahan dan ditimbun. Menahan penguasa atau tukang pos adalah pelanggaran, karena dengan demikian mereka dicegah dari menjalankan fungsinya; demikian pula halnya dengan uang” 22

\section{Peranan Negara dalam Sosio Ekonomi}

Meskipun menghindari aktivitas politik, Al-Ghazali memberikan komentar dan nasihat yang rinci mengenai tata cara urusan negara. Dalam hal ini, ia tidak ragu-ragu menghukum penguasa. Ia menganggap negara sebagai Lembaga yang penting, tidak hanya bagi berjalannya aktivitas ekonomi dari suatu masyarakat dengan baik, tetapi juga untuk memenuhi kewajiban sosial sebagaimana yang diatur oleh wahyu. Ia menyatakan:

'Negara dan agama adalah tiang-tiang yang tidak dapat dipisahkan dari sebuah masyarakat yang teratur. Agama adalah fondasinya, dan penguasa yang mewakili negara adalah penyebar dan pelindungnya; bila salah satu tiang ini lemah, masyarakat akan ambruk"23

Ia menambahkan bahwa ketidakmampuan manusia untuk memenuhi sendiri semua kebutuhannya mendorongnya untuk hidup dalam masyarakat yang beradap dengan kerja sama. Namun, kecenderungan seperti iri, persaingan dan egoism dapat menciptakan konflik. Oleh karena itu, diperlukan suatu aturan Bersama untuk mengurangi kecenderungan itu.

Seperti dinyatakan sebelumnnya, Al-Ghazali juga menitik beratkan peranan utama negara di antara keempat industry dalam kategori pertamanya, yakni sebagai suatu yang esensial untuk menjaga orang-orang agar hidup Bersama secara harmonis dan dalam kerja sama satu sama lain dalam mencari penghidupan. Negara harus berjuang untuk kebaikan masyarakat melalui kerja sama dan rekonsiliasi. $^{24}$

Walaupun tidak membahas dengan menggunakan peristiwa modern, AlGhazali telah mengidentifikasi dengan jelas berbagai jenis fungsi ekonomi yang dijalankan oleh Negara. Ia menitikberatkan bahwa untuk meningkatkan kemakmuran ekonomi, Negara harus menengakkan keadilan, kedamaian dan keamanan, serta stabilitas. Ia menekankan perlunya keadilan, serta aturan yang adil dan seimhlm 192

${ }^{22}$ Abu Hamid Al- Ghazali, Ihya Ulum al-Din (Beirut: Dar al-Nadwah, t.t.), Juz 4,

${ }^{23}$ Abu Hamid Al- Ghazali, Book of Counsel for King (Nasibat al-Muluk) (New York and London: Oxford University Press, 1964), hlm.59

${ }^{24}$ Abu Hamid Al- Ghazali, Ihya Ulum al-Din (Beirut: Dar al-Nadwah, t.t.), Juz 2, hlm 13

120 | FalASIFA, Vol. 10 Nomor 1 Maret 2019 
bang:

"Bila terjadi ketidakadilan dan penindasan, orang tidak memiliki pijakan; kota-kota dan daerah-daerah menjadi kacau, penduduknya mengungsi dan pindah ke daerah lain, sawah dan ladang ditinggalkan, kerjaan menuju kehancuran, pendapatan publik menurun, kas Negara kosong, dan kebahagiaan serta kemakmuran dalam masyarakat menghilang. Orang-orang tidak mencintai penguasa yang tidak adil, alih-alih mereka selalu berdoa semoga kemalangan menimpanya." 25

Ia menekankan bahwa Negara harus mengambil semua tindakan yang perlu untuk menegakkan kondisi keamanan internal dan eksternal:

"Tentara diperlukan untuk mempertahankan dan melindungi orang-orang dari perampok. Harus ada pengadilan untuk menyelesaikan sengketa, hukum dan peraturan diperlukan untuk mengawasi perilaku orang-orang dan untuk stabilitas sosial...hal-hal itu merupakan fungsi-fungsi penting pemerintah yang hanya dapat dijalankan oleh ahlinya, dan bila mereka menjalankan aktivitas-aktivitas ini, mereka tidak dapat meluangkan waktu untuk terlibat dalam industry lainnya dan mereka memerlukan dukungan bagi penghidupannya. Di lain pihak, orang membutuhkan mereka karena jika semua bekerja di bidang pertahanan, industry lainnya akan terbengkalai dan jika tentara terlibat dalam industri-industri untuk mencari penghidupan mereka, maka negeri-negeri tersebut akan kekurangan pembela-pembelanya dan orang akan menjadi korban. ${ }^{26}$

Dengan demikian, tampak jelas bahwa Al-Ghazali berpendapat Negara bertanggung jawab dalam menciptakan kondisi yang layak untuk meningkatkan kemakmuran dan pembangunan ekonomi. Di samping itu ia juga menulis secara panjang lebar mengenai lembaga al-Hisbah, sebuah badan pengawas yang dipakai di banyak Negara Islam pada waktu itu. Fungsi utama badan ini adalah untuk mengawasi praktik-praktik pasar yang merugikan. Al-Ghazali sangat mendukung lembaga ini dan mendiskusikan jenis-jenis praktik yang harus diawasi, seperti pengakuan palsu tentang laba, iklan palsu, timbangan dan ukuran yang tidak benar, transaksi yang keterlaluan, kontrak yang cacat, transaksi barang-barang haram, dan semua kesepakatan lainnya yang mengandung penipuan, dan lain-lain. ${ }^{27}$

Gambaran Al-Ghazali mengenai peranan khusus yang dimainkan oleh $\mathrm{Ne}$ -

${ }^{25}$ Abu Hamid Al- Ghazali, The Book of Counsel, hlm. 56

${ }^{26}$ Abu Hamid Al- Ghazali, Ihya Uhm al-Din (Beirut: Dar al-Nadwah, t.t.), Juz 3, hlm 225 dan 228

${ }^{27}$ Ibid, Juz 2., hlm 338

FaLASIFA, Vol. 10 Nomor 1 Maret 2019 | 121 
gara dan penguasa dituliskan dalam sebuah buku tersendiri yang berjudul kitan Nasibat-al-Muluk (Buku Nasihat untuk Para Raja). Di dalam kitab ini ia merekomendasikan untuk para raja sepuluh prinsip- prinsip keadilan dan perlakuan yang adil terhadap warga Negara. ${ }^{28}$ Setiap prinsip tersebut tidak hanya dibahas dari sudut pandang Islam, tetapi juga didukung dengan ilustrasi dari Taurat dan Injil, dan juga dari sejarah Romawi, Yunani dan bahkan Cina. Di antara prinsip tersebut, Al-Ghazali memperingatkan penguasa untuk tidak menyalahgunakan kekuasaan, sombong, terbuai oleh sanjungan, serta bersikap waspada terhadap ulamaulama palsu.

Disamping memberi nasihat pada penguasa, Al-Ghazali melihat banyak hal yang harus dikritik, dan ia sering kali melakukannya dengan menggunakan istilahistilah yang pedas. Ia mengutuk penyuapan dan korupsi yang terjadi di sector public, khususnya dalam lembaga penegak keadilan. Dengan nada yang sama, ia memperingatkan penguasa agar tidak larut dalam memperturutkan hasrat-hasrat duniawi- sesuatu yang tidak hanya bertentangan dengan nilai-nilai Islam, tetapi juga mengganggu penyelenggaraan Negara.

\section{Public Finance}

Al-Ghazali memberikan penjelasan yang rinci mengenai peran dan fungsi keuangan public. Tidak seperti mayoritas ilmuwan lainnya, pembahasan yang dilakukan Al-Ghazali cukup simetris. Ia memperhatikan kedua sisi anggaran, baik sisi pendapatan maupun sisi pengeluaran. Berkaitan dengan berbagai sumber pendapatan Negara, Al-Ghazali memulai dengan pembahasan mengenai pendapatan yang seharusnya dikumpulkan dari seluruh penduduk, baik Muslim maupun NonMuslim, berdasarkan hukum Islam. Terdapat perbedaan dalam berbagai jenis pendapatan yang dikumpulkan dari setiap kelompok. Terhadap masyarakat Muslim, Al-Ghazali mengidentifikasi beberapa sumber pendapatan. Namun, bersikap kritis terhadap sumber- sumber haram yang digunakan. Dalam hal ini, Al-Ghazali menyatakan bahwa hamper seluruh pendapatan yang ditarik oleh para penguasa di zamannya melanggar hukum. Oleh karena itu, para pembayar pajak seharusnya menolak untuk membayar pajak serta menghindari hubungan dengan mereka. Lebih jauh, ia merasa bahwa sistem pajak yang sedang berlaku didasarkan atas adat kebiasaan yang sudah lama berlaku, bukan berdasarkan hukum Ilahi.

Al-Ghazali menyebutkan bahwa salah satu sumber pendapatan yang halal adalah harta tanpa ahli waris yang pemiliknya tidak dapat dilacak, ditambah sum-

${ }^{28}$ Abu Hamid Al- Ghazali, Book of Counsel for King (Nasibat al-Muluk) (New York and London: Oxford University Press, 1964), hlm.13-31

122 | FalAsIfA, Vol. 10 Nomor 1 Maret 2019 
bangan sedekah atau wakaf yang tidak ada pengelolanya. Adapun zakat dan sedekah, ia mengungkapkan bahwa kedua sumber pendapatan tersebut tidak ditemukan pada zamannya:

"Keuangan publik di masa kita, seluruhnya atau sebagiannya, didasarkan atas sumber- sumber haram. Kenapa? Karena sumber- sumber yang sah seperti zakat, sedekah, fai, dan ghanimah tidak ada. Jizyah memang diberlakukan tetapi dikumpulkan dengan banyak cara yang illegal. Di samping itu, terdapat banyak jenis retribusi yang dibebankan kepada umat Muslim- ada penyitaan, penyuapan dan banyak ketidakadilan." ${ }^{29}$

Pajak-pajak yang dikumpulkan dari Non- Muslim berupa ghanimah, fai, jizyah dan upeti atau amwal al-Masalih. Ghanimah atau harta rampasan perang adalah pajak atas harta yang disita setelah atau selama perang. Fai adalah kepemilikan yang diperoleh tanpa melalui peperangan. Jizyah dikumpulkan dari kaum NonMuslim sebagai imbalan dari dua keuntungan: pembebasan wajib militer dan perlindungan hak- hak sebagai penduduk. Negara dapat menetapkan pajak "ekstrareligius" terhadap semua penduduk, melampaui sumber- sumber pendapatan yang diatur agama, dan tergantung pada kebutuhan masyarakat. Hal ini dapat pula dilakukan jika masyarakat dalam keadaan terancam.

Al-Ghazali menyarankan agar dalam memanfaatkan pendapatan Negara, Negara bersikap fleksibel yang berlandaskan kesejahteraan. Ia mengusulkan bahwa jika pengeluaran public dapat memberikan kebaikan sosial yang lebih banyak, penguasa dapat memungut pajak baru. Ia menjelaskan:

"Kerugian yang diderita orang karena membayar pajak lebih kecil bila dibandingkan dengan kerugian yang muncul akibat resiko yang mungkin timbul terhadap jiwa dan harta mereka jika Negara tidak dapat menjamin kelayakan penyelenggaraannya"30

Apa yang dikemukakan oleh Al-Ghazali tersebut merupakan cikal bakal dari apa yang sekarang disebut sebagai analisis biaya- manfaat, yakni pajak dapat dipungut untuk menghindari kerugian yang lebih besar di masa yang akan datang. Di samping itu, Al-Ghazali juga memberikan pemikiran tentang hal-hal lain yang berkaitan dengan permasalahan pajak, seperti administrasi pajak dan pembagian beban di antara para pembayar pajak. Ia memperingatkan, hlm 239

${ }^{29}$ Abu Hamid Al- Ghazali, Ihya Ulum al-Din (Beirut: Dar al-Nadwah, t.t.), Juz 3,

${ }^{30}$ Abu Hamid Al- Ghazali, Al-Mastarfa min Ilmu Zal Usul ( Bulaque: al- Maktabah al- Amriyah), hlm. 303-304

FalASIFA, Vol. 10 Nomor 1 Maret 2019 | 123 
"Penguasa jangan sampai memberi toleransi terhadap pemerasan atas warga Negara oleh pejabat manapun...penguasa harus menjaga masyarakat seperti ia menjaga rumahnya sendiri, sehingga masyarakat dapat menjadi makmur dan berkembang. Apa yang ia ambil dalam bentuk pajak harus sedang, dan apa yang ia berikan harus sedang pula; karena masing-masing memiliki batas dan ukuran-ukurannya. ${ }^{31}$

Pernyataannya tersebut sekaligus mengindikasikan bahwa Al-Ghazali mengenali pula prinsip- prinsip perpajakan benefits received dan ability-to-pay yang digunakn dalam literarur- literature terkini. Ia menyatakan basis quid-pro-quo dari pajak-pajak tertentu ketika ia membahas pajak yang benefit-related dari jizyah. Namun demikian, berdasarkan prinsip umum keadilan, ia menganjurkan konsep kemampu-bayaran; sebuah konsep yang dimaksudkan sebagai sebuah sistem pajak yang sangat progresif. Ia bahkan menyarankan agar pembayar pajak mengetahui pemanfaatan sumber daya mereka.

"Jika mereka [penguasa] meminta pendapatan dari warga negaranya, mereka harus hanya meminta pada waktu dan musim yang sesuai. Warga Negara harus tahu pemanfaatannya dan beban harus ditetapkan sesuai dengan kapasitas dan kemampuannya (untuk membayar). Mereka [penguasa] harus menjadi 'pembunuh burung bangau pada waktu berburu, bukan pembunuh burung pipit. Yakni, mereka harus mengambil sedikit atau tidak mengambil apa pun dari orang miskin. ${ }^{32}$

Al-Ghazali merupakan seorang di antara sedikit ilmuwan pada masanya yang membahas utang public sebagai sumber pendapatan Negara lainnya. Ia menyatakan,

"Seseorang tidak dapat menafikan bolehnya penguasa untuk meminjam dari rakyat bila kebutuhan Negara menuntutnya. Namun demikian, pertanyaannya adalah: jika penguasa tidak mengantisipasi pendapatan dalam Baitul Mal yang dapat melebihi apa yang dibutuhkan bagi tentara dan pejabat public lainnya, maka atas dasar apa dana-dana itu dapat dipinjam?.”33

Dari pertanyaannya ini, tampak bahwa dengan melihat kondisi ekonomi, Al-Ghazali mengizinkan utang publik jika memungkinkan untuk menjamin pembayaran kembali dari pendapatan di masa yang akan datang. Pada masa kini, con-

${ }^{31}$ Abu Hamid Al- Ghazali, Book of Counsel for King (Nasibat al-Muluk) (New York and London: Oxford University Press, 1964), hlm.80-81

${ }^{32}$ Ibid., hlm. 112

${ }^{33}$ Abu Hamid Al-Ghazali, Syifa al-Ghalil, hlm. 241

124 | FaLASIFA, Vol. 10 Nomor 1 Maret 2019 
toh utang seperti ini adalah revemue bonds yang digunakan secara luas oleh pemerintah pusat dan lokal di Amerika Serikat.

Berkenaan dengan sumber pendapatan Negara yang ada pada masa hidupnya, Al-Ghazali juga bersikap kritis mengenai tata cara dan wilayah pengeluaranpublik. Ia menyatakan,

"Pada saat ini, penguasa tidak memberikan imbalan pada orang yang pantas menerimanya, tetapi mereka member imbalan pada orang-orang yang mereka pandang berguna untuk mengamankan kepentingan mereka, pada orang-orang yang menghiasi istana-istana mereka, dan pada orang-orang yang dapat dimanfaatkan untuk memuji-memuji mereka dan memberikan penghargaan baik di hadapan mereka maupun dibelakang mereka."34

Penggambaran fungsional dari pengeluaran publik yang direkomendasikan Al-Ghazali bersifat agak luas dan longgar, yakni penegakan keadilan sosio- ekonomi, keamanan dan stabilitas Negara, serta pengembangan suatu masyarakat yang makmur.

Selain dari apa yang telah diutarakan mengenai bagaimana menciptakan kondisi-kondisi tersebut, dapat dikatakan bahwa walaupun memilih pembagian sukarela sebagai suatu cara untuk meningkatkan keadilan sosio-ekonomi, AlGhazali membolehkan intervensi Negara sebagai pilihan bila perlu, untuk mengeliminasi kemiskinan dan kesukaran yang meluas:

"Bila rakyat sultan jatuh miskin atau mengalami kesukaran, maka merupakan tugasnya [sultan] untuk membantu, khususnya pada masa-masa kekeringan atau ketika mereka tidak mampu mencari penghidupan (karena harga-harga melambung). [karenanya] raja harus menyediakan makanan dan member bantuan kepada raktanya, serta menjamin bahwa pejabatpejabatnya tidak menekan rakyat karena jika hal itu terjadi, rakyat akan menjadi miskin dan meninggalkan daerahnya. Aliran pendapatan akan berhenti, laba akan dinikmati oleh penimbun, dan sang sultan akan [mendapat] kutukan dan nama buruk. Karena alasan-alasan inilah para penguasa pada zaman dulu mempraktikkan penghematan sepenuhnya dalam keadaan-keadaan demikian, dan karenanya membantu warga Negara yang layak dibantu." ${ }^{\$ 35}$

Dengan jelas Al-Ghazali mengaitkan pemiskinan rakyat (yang diperburuk dengan kurangnya layanan publik) dengan perpindahan mereka, yang mengakibatkan penurunan ekonomi secara umum, penurunan basis pajak, dan kemerosohlm 130

${ }^{34}$ Abu Hamid Al- Ghazali, Ihya 'Ulum al-Din (Beirut: Dar al-Nadwah, t.t.), Juz 3,

${ }^{35}$ Ibid., 140

FalASIFA, Vol. 10 Nomor 1 Maret 2019 | 125 
tan lebih jauh, serta potensi timbulnya para pencari untung yang mengeksploitasi orang miskin.

Mengenai perkembangan masyarakat secara umum, Al-Ghazali menunjukkan perlunya membangun infrastruktur sosio- ekonomi. Ia berkata bahwa sumber daya publik :

"Seharusnya dibelanjakan untuk pembuatan jembatan-jembatan, bangunanbangunan keagamaan (masjid), pondokan, jalan-jalan dan aktivitas lainnya yang senada yang manfaatnya dapat dirasakan oleh rakyat secara umumnya." ${ }^{36}$

Pernyataan tersebut menunjukkan bahwa Al-Ghazali mengakui "konsumsi bersama" dan aspek spill- over dari barang-barang public. Di lain tempat, ia menyatakan bahwa pengeluaran publik dapat diadakan untuk fungsi-fungsi seperti pendidikan, hokum dan administrasi public, pertahanan, dan pelayanan kesehatan.

Di samping itu, Al-Ghazali menekankan kejujuran dan efisiensi dalam urusan si sector public. Ia memandang perbendaharaan public sebagai amanat yang dipegang oleh penguasa, yang tidak boleh bersikap boros. Mengenai lingkungan sosial yang stabil dan aman, ia menjelaskan. "Bilamana Sultan [penguasa] memerintah secara opresif, ketidakamanan akan muncul; dan bagaimanapun makmurnya masyarakat, hal ini tidak akan menyenangkan warga Negara bila tidak diiringi dengan keamanan. Bagaimanapun sedikitnya kemakmuran yang ada, hal ini tidak akan mengecewakan mereka bila diiringi oleh keamanan; sebaliknya, hal ini akan menyenangkan mereka...Kini keamanan masyarakat bergantung pada disiplin yang dijaga oleh Sultan. ${ }^{37}$

\section{KESIMPULAN}

Demikian peneleaahan pemikiran ekonomi salah satu cendekiawan muslim terkemuka Abu Hamid Al-Ghazali, beliau menegaskan bahwa maslabah atau kesejahteraan dari suatu masyarakat tergantung kepada pencarian dan pemeliharaan lima tujuan dasar, yakni al-dien/(agama), nafs (hidup atau jiwa), nasl (keluarga atau keturunan), mal (harta atau kekayaan), dan aql (intelektual/akal). Ia menitikberatkan bahwa sesuai tuntunan wahyu, tujuan utama kehidupan umat manusia adalah untuk mencapai maslahat al-din wa al-dunya (kebaikan dunia dan akhirat). Selanjutnya Ia juga menjelaskan secara rinci tentang aktivitas produksi, evolusi pasar, permintaan dan penawaran, problema barter serta larangan tentang riba. Keselu-

\footnotetext{
${ }^{36}$ Ibid., 101-102

${ }^{37}$ Abu Hamid Al- Ghazali, Book of Connsel for King (Nasibat al-Muluk) (New York and London: Oxford University Press, 1964), hlm.76
}

126 | FaLASIFA, Vol. 10 Nomor 1 Maret 2019 
ruhan topik ia jelaskan secara kompleks dan sangat mendalam.

\section{DAFTAR PUSTAKA}

Ghazanfar, S. M. dan Abdul Azim Islahi, Economic Thought of An Arab Scholastic: Abu Hamid Al-Ghazali, dalam History of Political Economy, Durham: Duke University Press, 1990, Vol. 2, No. 22

Karim, Adimarwan Azwar, Sejarah Pemikiran Ekonomi Islam, Jakarta: Rajawali Pers, 2016

Al- Ghazali, Abu Hamid, Ihya Ulum al-Din, Beirut: Dar al-Nadwah, t.t

Lowry, S. Tood, The Archeology of Economic Ideas: The Classical Greek Tradition, Durham: Duke University Press, 1987

Al-ghazali , Abu Hamid, Mizan al-Amal, Kairo: Dar al-Ma’arif, 1964

Al-Ghazali, Abu Hamid, Kimiya-e-Sa'adat, Lahore: Naashraan-e-Quran Ltd, 1973

Al- Ghazali , Abu Hamid, Book of Counsel for King (Nasibat al-Muluk), New York and London: Oxford University Press, 1964

Al- Ghazali, Abu Hamid, Al-Mastarfa min Ilmu Zal Usul, Bulaque: al- Maktabah al- Amriyah, t.t

Al- Ghazali , Abu Hamid, Syifa al-Ghalil, t.p., t.t 
Uliyatul Mu'awwanah

128 | FaLASIFA, Vol. 10 Nomor 1 Maret 2019 